Article

\title{
Scotland's Food and Drink Policy Discussion: Sustainability Issues in the Food Supply Chain
}

\section{Philip Leat *, Cesar Revoredo-Giha and Chrysa Lamprinopoulou}

Food Marketing Research, Land Economy and Environment Research Group, Scottish Agricultural College (SAC), West Mains Road, Edinburgh EH9 3JG, UK;

E-Mails: cesar.revoredo@sac.ac.uk (C.R.-G.); chrysa.lamprinopoulou@sac.ac.uk (C.L.)

* Author to whom correspondence should be addressed; E-Mail: philip.leat@ sac.ac.uk; Tel.: +44-1224-711048; Fax: +44-1224-711270.

Received: 23 February 2011 / Accepted: 29 March 2011 / Published: 31 March 2011

\begin{abstract}
The purpose of the paper is two-fold. First, to identify the main sustainability issues that Scottish food supply chain actors are concerned with and any differences that exist between primary producers, processors and distributors and consumers; and second, to explore the implications of respondents' views for the direction of food and drink policy in Scotland. The analysis was based on a dataset assembled from the written responses to the National Food Policy discussion in Scotland, which contains opinions on the different dimensions of sustainability (economic, environmental and social) from a broad range of individuals and organizations representing different segments of the Scottish population. The empirical analyses involved comparing the responses according to two criteria: by food supply chain stakeholder and by geographical region. The results indicated that whilst there were differences among the studied groups, the importance of social and economic sustainability were strongly evident in the foregoing analysis, highlighting issues such as diet and nutrition, the importance of local food, building sustainability on sound economic performance, the market power of supermarkets, and regulation and support in building human and technical capabilities.
\end{abstract}

Keywords: food sustainability; food supply chain; food policy 


\section{Introduction}

The food and drink supply chain is a key part of the Scottish economy accounting for almost $20 \%$ of total Scottish gross value added (GVA) and employs over 360,000 people across Scotland. The population of just over five million people represents a relatively small domestic market and consequently there is a strong export orientation in much of the food and drink sector, with total annual exports being worth over $£ 5$ billion. Agricultural production itself is dominated by livestock and meat production, and meat accounts for approximately $21 \%$ of consumers' total expenditure on food. Scotland's (poor) diet is widely regarded as contributing to high obesity levels and as a cause of major chronic diseases and shortened life expectancy (a brief description of the Scottish food and drink sector is provided in Appendix 1).

On 7 November 2007 the Scottish Parliament resolved that "Scotland should have a national food policy and would benefit greatly by having a clear, consistent and coherent approach to food covering health, environmental, social, cultural and economic factors and welcomes the Scottish Government's commitment to launch a national debate and consultation on a food policy for Scotland that takes into account the views of the Parliament, industry and wider society" [1]. Behind this resolution lay recognition that the development of enterprise, health, rural affairs and other policy areas in Scotland all have a food dimension and that as such needed to point in the same direction [1].

The national debate was launched in January 2008 with the release of a discussion paper: 'Choosing the Right Ingredients - the Future for Food in Scotland' [2]. This set out Government's vision for food in Scotland and was structured around five strategic objectives: (1) 'Healthier Scotland', which embraced individual behavior and attitudes about diet and food choices; (2) 'Wealthier and fairer Scotland', which considered sustainable economic growth of the food industry; (3) 'Safer and stronger Scotland', which dealt with a food industry and its interaction with local communities; (4) 'Greener Scotland', which presented views on reducing the environmental impact of food and drink production and consumption; and (5) 'Smarter Scotland', which addressed creating a highly-skilled and innovative food industry with better informed consumers.

The discussion document also presented many of the main challenges and issues associated with food in Scotland. As such, there were no predetermined questions for respondents to consider, as in the case of a formal consultation, and the participants were invited to provide opinions about any of the document's topics, or even raise additional ones. A further element of the discussion was a series of 13 stakeholder events held across Scotland for views to be expressed and communicated to Government. In total 605 individuals, with 315 organizations being represented, were involved in these events. In addition, a blog was placed on the Scottish Government website with five video clips which presented a variety of issues by prominent members of the food community and which could be responded to by an on-line response facility. Overall, 80 people commented on the blog.

The opinions collected through the discussion were used to inform the policy development process. Notably, five workstreams (i.e., working groups) were established to consider key areas of the developing policy. In addition a Food and Drink Leadership Forum was set up with 'champions' to cover the fundamentals of health, environment, affordability and the economy. The forum was tasked with making recommendations to the Scottish Government based on the workstreams reports. In June 2009 the new policy was launched with the publication of 'Recipe for Success-Scotland's National 
Food and Drink Policy' [3] (note that while the discussion was termed a National Food Policy discussion, the importance of drink production and consumption subsequently led to the policy becoming a Food and Drink Policy).

At the end of the discussion period in late April 2008, a total of 441 individuals and organizations had made written responses to the Government. A sub-product of the analysis of the responses to the discussion document was a unique dataset containing opinions on the different dimensions of food sustainability from a broad range of individuals and organizations representing different segments of the Scottish population.

The assembled database allowed us to explore the breadth of interests of the Scottish population as regards the different dimensions of sustainability of the food system. This is an important issue due to the fact that diverse understandings of sustainability complicate the development of a cohesive and applicable policy agenda, which can be accepted and deployed across the whole food supply chain. Different patterns of emphasis placed on sustainability by individual stakeholders in the supply chain can contribute to distorted interpretations and objections towards specific policy goals and associated measures. As suggested in previous research focusing on agri-food chains and sustainability [4-6], there could be substantial disparities in the sustainability concerns and priorities for individual groups of stakeholders and no overall definition of sustainability might be found for society as a whole. Furthermore, the expectations of multiple stakeholders may necessitate and influence a complex relationship process requiring separate consideration of particular interest groups $[7,8]$.

In addition, it should be noted that the otherwise divergent sustainability agendas of individual stakeholders could intersect, and emerging common interest could be used as both communication and action platforms for co-operation between supply chain members. The intra-chain synergy could then be a part of a larger, localized sustainable production system for a whole sector within a country, specializing in the production of a specific food product that faces serious sustainability related challenges, as in the case of the Scottish salmon industry [9]. Identification of differences and common grounds shared by food supply chain stakeholders is therefore a critical starting point for both industry based sustainability strategies and food policy measures. Hence there is a need for a clear definition and understanding of sustainability, its attributes and benefits and the recognition of any ethical prerogative attached to trade-offs faced by food chain stakeholders.

The aims of this paper are: first, to identify the main sustainability issues that Scottish food supply chain actors are concerned with and any differences that exist between primary producers, processors and distributors and consumers; and second, to explore the implications of respondents' views for the direction of food and drink policy in Scotland.

The structure of the paper is as follows. Following this introduction, the second section discusses the different dimensions of the sustainability concept. The third section deals with the empirical analysis, which comprises a description of the assembled dataset and the methodology used to analyze the data. The fourth section discusses the results, which comprises an analysis by supply chain stakeholder groups and another by region. Policy implications are also considered in this section. Finally, conclusions are presented. 


\section{The Different Dimensions of Sustainability}

The framework used to analyze the responses to the National Food Policy discussion follows the belief that sustainable development is "development that meets the needs of the present without compromising the ability of future generations to meet their own needs" [10]. Moreover, it considers that the concept of sustainability is multidimensional [11] as it includes economic, environmental and social dimensions. The framework is presented in Figure 1.

The economic dimension relates to the efficient use of resources, the competitiveness and the viability of the food sector as well as its contributions to society. The environmental dimension 'refers above all to the management of natural resources with a view to ensuring that they are available in the future. However, it also includes issues such as the protection of landscapes, habitats, biodiversity, as well as the quality of drinking water and air' [11], and the social dimension relates here to questions of labor opportunities, community development and human welfare.

As shown in Figure 1, there is interdependency between these different dimensions. Thus, strengthening the economic viability of different groups is the basis for providing the means of preserving their social and environmental functions (e.g., rural communities). Social implications, such as the maintenance of a strong, healthy and just society, result from the provision of employment opportunities within for example the food chain (giving rise to an equitable situation without imbalances between, for instance, rural and urban areas, or the different stakeholders within the food chain). Similarly, preserving environmental quality, such as the prudent use of agricultural land, is also a precondition for developing a lasting economic potential in different communities such as in rural areas [11].

Figure 1. Dimensions of sustainability. Based on [12].

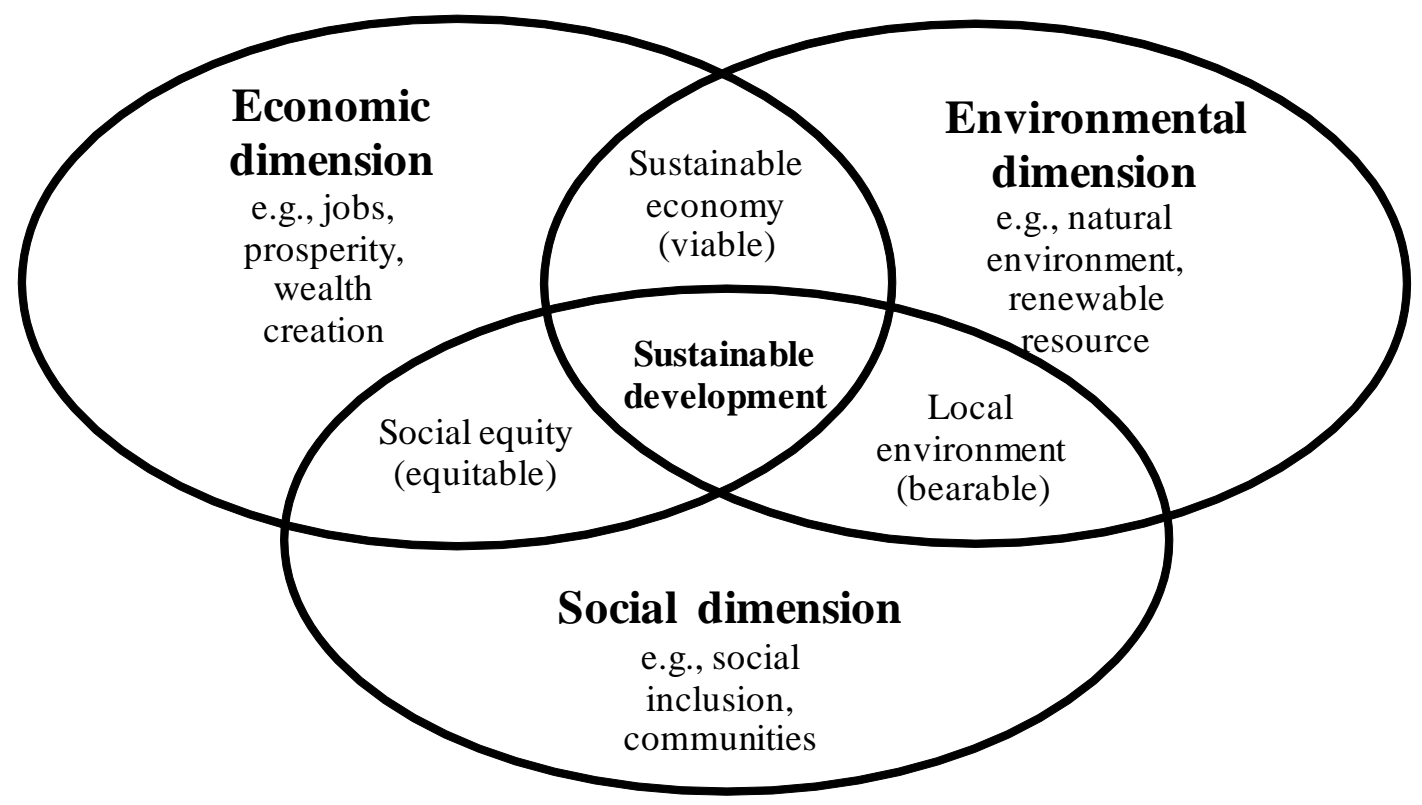

It should be noted that although the economic, social and environmental dimensions can to a certain degree develop synergies, this is not always true as they can compete with each other requiring a balance to be achieved between the three dimensions. As mentioned by the EC [11] "Political choices 
concerning one out of these three elements must at least ensure that certain minimum standards with respect to the other two are observed".

\section{Empirical Analysis}

The empirical methodology used to analyze the data consisted of several steps: first, the dataset was assembled using the responses to the National Food Discussion; second, each response was coded according to its contents; and third, a frequency distribution analysis was carried out in order to rank the responses by stakeholder activity and region.

\subsection{Assembling the Dataset}

The dataset was assembled based on the written responses to the aforementioned discussion document, with responses totaling 441. Table 1 presents the distribution of the responses by Scottish geographic region and supply chain stakeholder activity.

Table 1. Summary of characteristics of the stakeholders submitting responses.

\begin{tabular}{lccc}
\hline Variables & Cases & $\begin{array}{c}\text { Distribution } \\
(\mathbf{\%})\end{array}$ & $\begin{array}{c}\text { Intensity 6/ } \\
\text { (\%) }\end{array}$ \\
\hline Total number of responses & 441 & 100.0 & \\
Geographic region 1/ & & & 310.8 \\
North West & 64 & 14.5 & 96.6 \\
North East & 41 & 9.3 & 104.7 \\
South East & 168 & 38.1 & 61.5 \\
South West & 126 & 28.6 & \\
Out of Scotland & 22 & 5.0 & \\
$\quad$ No information provided & 20 & 4.5 & \\
Stakeholder activity & & & \\
Consumers & 373 & 84.6 & \\
Producers 2/ & 30 & 6.8 & \\
$\quad$ Processors 3/ & 8 & 1.8 & \\
Retailers 4/ & 20 & 4.5 & \\
Industry bodies 5/ & 10 & 2.3 & \\
\hline
\end{tabular}

Notes: 1/ The North West comprises the relatively remote and rural Highlands and Islands. The North East includes the major oil city of Aberdeen and its surrounding rural counties. The South East includes the cities of Dundee and Edinburgh and runs south to the Scottish Borders. The South West includes Glasgow and much of the urban area of central Scotland, as well as the rural South West down to Dumfries and Galloway which borders North West England.

2/ Farmers, fishermen or organizations related to them.

3/ Processors (i.e., butchers) or organizations related to them.

4/ Retailers or organizations related to them.

5/ Organizations that encompass producers, processors and retailers.

6/ Index constructed as the ratio of the responses in a region to its population. The base of the index is 100 , which is the case for Scotland as a whole. 
In the case of the regional distribution, as shown in Table 1, there was a proportionately high level of responses from the South East (38\%) and South West (29\%), and a proportionately low response from the North West (14.5\%). The North East represented 9\% of responses. In addition to the regional distribution of responses, a coefficient representing the intensity of the response ('coefficient of intensity') in each region was constructed. As shown, the intensity of response differed by region, with the North West having the highest index value (311\%). Note that the coefficient of intensity was not calculated for the supply chain stakeholder classification due to the lack of information about the population of each group.

Primary producers, food processing businesses and retailers, as well as industry bodies (i.e., organizations producers, processors and retailers), were the food chain respondent categories. Members of the public were expressing their views as individual consumers and citizens and constituted the most numerous group of stakeholders (see Table 1 above). It is worth noting that while only limited numbers of farmers, processors and retailers participated in the discussion, most of the major organizations representing these different stakeholder groups contributed their views. The fact that all major UK multiple retailers participated, together with a large number of Scottish consumers, provided an interesting insight into issues arising in the context of market balance between consumers and their immediate retail suppliers. The presence of supermarkets in the sample is particularly interesting, because they see themselves as always responding to consumer demands, but they also shape consumers' preferences by managing the mix of products, promotional efforts and the product assortment available for purchase. Hence, multiple retailers could be seen as a driving force in food supply chains both in terms of chain operation and participant practices, as well as food type availability, and could therefore be considered as a major target for policy makers if any significant change is to be effected $[13,14]$.

\subsection{Methodology}

The discussion gave rise to representations from a broad range of individuals and organizations both from within Scotland and from outside, and collectively they raised a wide variety of issues that might be addressed by a national food and drink policy [15].

To cope with this breadth of issues, a significant part of the analysis involved categorizing each response according to a set of 37 topics. It should be noted that these topics were not selected ex-ante for the analysis of the documents, but were developed by adding new topics or refining the content of the existing ones as the analysis of responses progressed and new topics emerged. Thus, after the classification of the documents one stakeholder may (as happened frequently) be associated with quite a range of topics (more than 20 in some cases). In order to reduce the level of subjectivity in the identification of broad topics in the responses, the exercise was performed independently by two researchers within the team and their results were compared to obtain a final representation of stakeholders' references to the topics.

The next step of the analysis consisted of ranking the different topics according to the number of stakeholders (which were classified according to different categories, namely geographical location and position in the supply chain, amongst others) that included them in their responses. It should be noted that this analysis did not take into account the intensity of expression associated with a topic in a 
stakeholder's response (e.g., the number of times that a topic appears in the response). In addition, each stakeholder was given a weight equal to one, whether it was an individual or an organization.

A definition of the topics is presented in Table A-1 in Appendix 2, which also classifies the topics by the sustainability dimensions.

\section{Results and Policy Implications}

Table 2 provides a record of the distribution of responses by the main food supply chain stakeholders according to the topic categories which were specified for the analysis. The topics have also been classified into the economic, social and environmental dimensions of sustainability. It should be recognized that this classification is complicated by the fact that some of the topics embrace two or even three of the dimensions of sustainability. Thus, for example, 'local food and local economies' which is defined as 'the impact of the Scottish food industry on regional employment, income and general welfare-including Government financial support for farmers and the food sector' relates both to social and economic issues. It has, however, been classified as part of the social dimension of sustainability for this analysis. Other topics, such as 'diet and nutrition' are more clearly focused on one dimension of sustainability, in this case the social dimension. It is contended that this complication does not diminish the following analysis.

\subsection{Primary Producers-Farmers and their Organizations}

Amongst primary producers many of the responses were focused on the profile of production and issues facing the individual farms. Overall, the factors influencing farmers' responses could be divided into individual and institutional ones [16]. Institutional factors tended to be more general and formed common denominators for most of the respondents, whereas individual ones pertained more to the specific situations of respondents. Amongst the latter category were the geographical location of farmers (e.g., poor availability of certain services such as abattoirs, distance from the market), profile of production (animal production seems to be faced with a more challenging market environment and also more scrutiny coming from consumers as well as from public and regulatory/legislative bodies) and farmers' characteristics (e.g., age and experience). Institutional/general factors mentioned were a lack of understanding of the farming and food sector by consumers and political decision makers alike, along with gaps in public food education and a media biased portrayal of farmers. 
Table 2. Rankings of topic areas by stakeholder typology (blue $=$ economic, green $=$ environmental and red $=$ social).

\begin{tabular}{|c|c|c|c|c|c|c|c|c|c|}
\hline \multicolumn{2}{|l|}{ Primary producers } & \multicolumn{2}{|l|}{ Processors } & \multicolumn{2}{|l|}{ Retailers } & \multicolumn{2}{|l|}{ Industry bodies } & \multicolumn{2}{|l|}{ Consumers } \\
\hline Topic areas & Cases & Topic areas & Cases & Topic areas & Cases & Topic areas & Cases & Topic areas & Cases \\
\hline Diet and nutrition & 18 & $\begin{array}{c}\text { Local food \& } \\
\text { local economies }\end{array}$ & 7 & Diet and nutrition & 20 & Diet and nutrition & 10 & Diet and nutrition & 245 \\
\hline Farming industry & 16 & Diet and nutrition & 5 & Food labelling & 16 & $\begin{array}{c}\text { Local food \& } \\
\text { local economies }\end{array}$ & 10 & $\begin{array}{c}\text { Local food \& } \\
\text { local economies }\end{array}$ & 170 \\
\hline $\begin{array}{c}\text { Local food \& } \\
\text { local economies }\end{array}$ & 16 & $\begin{array}{l}\text { Labour market- } \\
\text { skills, jobs }\end{array}$ & 5 & Health promotion & 16 & $\begin{array}{l}\text { Processing capacity } \\
\text { in Scotland }\end{array}$ & 8 & Health promotion & 156 \\
\hline $\begin{array}{l}\text { Environmentally friendly } \\
\text { food production }\end{array}$ & 13 & Adult education & 4 & $\begin{array}{c}\text { Local food \& } \\
\text { local economies }\end{array}$ & 15 & Farming industry & 7 & Education in schools & 149 \\
\hline Health promotion & 11 & $\begin{array}{c}\text { Capacity for } \\
\text { food production }\end{array}$ & 3 & $\begin{array}{l}\text { Food Chain } \\
\text { Collaboration }\end{array}$ & 12 & $\begin{array}{l}\text { Food Chain } \\
\text { Collaboration }\end{array}$ & 7 & Access to food & 143 \\
\hline Education in schools & 10 & Drinks industry & 3 & Access to food & 11 & $\begin{array}{l}\text { Labour market- } \\
\text { skills, jobs }\end{array}$ & 7 & Adult education & 131 \\
\hline Food labelling & 10 & $\begin{array}{l}\text { Environmentally friendly } \\
\text { food production }\end{array}$ & 3 & $\begin{array}{l}\text { Environmentally friendly } \\
\text { food production }\end{array}$ & 11 & Food labelling & 6 & Farming industry & 114 \\
\hline $\begin{array}{c}\text { Local food \& } \\
\text { local communities }\end{array}$ & 10 & $\begin{array}{l}\text { Food Chain } \\
\text { Collaboration }\end{array}$ & 3 & Food waste & 11 & Health promotion & 6 & $\begin{array}{l}\text { Environmentally friendly } \\
\text { food production }\end{array}$ & 112 \\
\hline $\begin{array}{l}\text { Processing capacity } \\
\text { in Scotland }\end{array}$ & 10 & Health promotion & 3 & Adult education & 10 & R\&D & 6 & $\begin{array}{c}\text { Local food } \& \\
\text { local communities }\end{array}$ & 108 \\
\hline Tourism & 10 & $\begin{array}{c}\text { Product market- } \\
\text { exports }\end{array}$ & 3 & $\begin{array}{l}\text { Labour market- } \\
\text { skills, jobs }\end{array}$ & 10 & $\begin{array}{l}\text { Environmentally friendly } \\
\text { food production }\end{array}$ & 5 & School \& hospital meals & 104 \\
\hline Access to food & 9 & R\&D & 3 & Education in schools & 9 & $\begin{array}{c}\text { Local food } \& \\
\text { local communities }\end{array}$ & 5 & Food labelling & 89 \\
\hline $\begin{array}{c}\text { External factors affecting } \\
\text { food supply }\end{array}$ & 9 & Access to food & 2 & Food packaging & 9 & Animal welfare & 4 & Grow your own & 88 \\
\hline
\end{tabular}


Table 2. Cont.

\begin{tabular}{|c|c|c|c|c|c|c|c|c|c|}
\hline \multicolumn{2}{|c|}{ Primary producers } & \multicolumn{2}{|l|}{ Processors } & \multicolumn{2}{|l|}{ Retailers } & \multicolumn{2}{|l|}{ Industry bodies } & \multicolumn{2}{|l|}{ Consumers } \\
\hline Topic areas & Cases & Topic areas & Cases & Topic areas & Cases & Topic areas & Cases & Topic areas & Cases \\
\hline $\begin{array}{c}\text { Product market- } \\
\text { public sector }\end{array}$ & 9 & Education in schools & 2 & $\begin{array}{c}\text { Local food \& } \\
\text { local communities }\end{array}$ & 9 & Education in schools & 4 & $\begin{array}{l}\text { Food and drink } \\
\text { advertising }\end{array}$ & 82 \\
\hline Adult education & 8 & Food miles (other) & 2 & Traceability & 9 & $\begin{array}{c}\text { External factors } \\
\text { affecting food supply }\end{array}$ & 4 & Organic production & 75 \\
\hline $\begin{array}{l}\text { Food Chain } \\
\text { Collaboration }\end{array}$ & 8 & $\begin{array}{c}\text { Processing capacity } \\
\text { in Scotland }\end{array}$ & 2 & Food safety & 8 & $\begin{array}{c}\text { Product market- } \\
\text { exports }\end{array}$ & 4 & $\begin{array}{c}\text { Product market- } \\
\text { supermarkets }\end{array}$ & 66 \\
\hline $\begin{array}{c}\text { Capacity for } \\
\text { food production }\end{array}$ & 7 & $\begin{array}{c}\text { Product market- } \\
\text { public sector }\end{array}$ & 2 & Local food \& food miles & 8 & $\begin{array}{c}\text { Product market- } \\
\text { public sector }\end{array}$ & 4 & Prices - consumer & 64 \\
\hline $\begin{array}{l}\text { Local food \& } \\
\text { food miles }\end{array}$ & 7 & $\begin{array}{c}\text { External factors } \\
\text { affecting food supply }\end{array}$ & 1 & Farming industry & 7 & Access to food & 3 & $\begin{array}{l}\text { Local food \& } \\
\text { food miles }\end{array}$ & 63 \\
\hline Organic production & 7 & Farming industry & 1 & Food and drink advertising & 7 & Drinks industry & 3 & $\begin{array}{l}\text { Product market- } \\
\text { public sector }\end{array}$ & 63 \\
\hline $\begin{array}{l}\text { Product market- } \\
\text { direct sales }\end{array}$ & 7 & Fishing Industry & 1 & Prices-consumer & 7 & Food and drink advertising & 3 & Food waste & 54 \\
\hline $\begin{array}{c}\text { Product market- } \\
\text { supermarkets }\end{array}$ & 7 & $\begin{array}{c}\text { Food and drink } \\
\text { advertising }\end{array}$ & 1 & Processing capacity in Scotland & 7 & Food miles (other) & 3 & Food packaging & 51 \\
\hline R\&D & 7 & Food labelling & 1 & Product market—public sector & 7 & Food waste & 3 & Animal welfare & 47 \\
\hline Animal welfare & 6 & Food safety & 1 & Animal welfare & 6 & $\begin{array}{c}\text { Product market- } \\
\text { supermarkets }\end{array}$ & 3 & Food miles (other) & 46 \\
\hline $\begin{array}{c}\text { Food and drink } \\
\text { advertising }\end{array}$ & 6 & Food waste & 1 & $\begin{array}{c}\text { External factors } \\
\text { affecting food supply }\end{array}$ & 6 & Traceability & 3 & $\begin{array}{c}\text { External factors } \\
\text { affecting food supply }\end{array}$ & 45 \\
\hline $\begin{array}{c}\text { Labour market- } \\
\text { skills, jobs }\end{array}$ & 6 & $\begin{array}{c}\text { Local food \& } \\
\text { local communities }\end{array}$ & 1 & Food miles (other) & 6 & Adult education & 2 & Fishing Industry & 45 \\
\hline $\begin{array}{c}\text { School \& } \\
\text { hospital meals }\end{array}$ & 6 & $\begin{array}{c}\text { School \& } \\
\text { hospital meals }\end{array}$ & 1 & $\begin{array}{c}\text { Product market- } \\
\text { supermarkets }\end{array}$ & 6 & $\begin{array}{c}\text { Capacity for } \\
\text { food production }\end{array}$ & 2 & Food safety & 45 \\
\hline
\end{tabular}


Table 2. Cont.

\begin{tabular}{|c|c|c|c|c|c|c|c|c|c|}
\hline \multicolumn{2}{|c|}{ Primary producers } & \multicolumn{2}{|l|}{ Processors } & \multicolumn{2}{|l|}{ Retailers } & \multicolumn{2}{|l|}{ Industry bodies } & \multicolumn{2}{|l|}{ Consumers } \\
\hline Topic areas & Cases & Topic areas & Cases & Topic areas & Cases & Topic areas & Cases & Topic areas & Cases \\
\hline Drinks industry & 5 & Traceability & 1 & $\begin{array}{c}\text { Capacity for } \\
\text { food production }\end{array}$ & 4 & Food safety & 2 & $\begin{array}{l}\text { Product market- } \\
\text { direct sales }\end{array}$ & 44 \\
\hline Food miles (other) & 5 & Animal welfare & 0 & Prices_-producer & 4 & $\begin{array}{l}\text { Local food \& } \\
\text { food miles }\end{array}$ & 2 & $\begin{array}{c}\text { Labour market- } \\
\text { skills, jobs }\end{array}$ & 43 \\
\hline Food safety & 5 & Fairtrade & 0 & R\&D & 4 & Prices - consumer & 2 & $\begin{array}{l}\text { Processing capacity } \\
\text { in Scotland }\end{array}$ & 42 \\
\hline Prices_consumer & 5 & Food packaging & 0 & Fishing Industry & 3 & Prices-producer & 2 & $\begin{array}{c}\text { Food Chain } \\
\text { Collaboration }\end{array}$ & 38 \\
\hline Traceability & 5 & Grow your own & 0 & Organic production & 3 & $\begin{array}{l}\text { Product market- } \\
\text { direct sales }\end{array}$ & 2 & Tourism & 33 \\
\hline $\begin{array}{c}\text { Product market- } \\
\text { exports }\end{array}$ & 4 & $\begin{array}{l}\text { Local food \& } \\
\text { food miles }\end{array}$ & 0 & Tourism & 3 & $\begin{array}{c}\text { School \& } \\
\text { hospital meals }\end{array}$ & 2 & $\begin{array}{c}\text { Capacity for } \\
\text { food production }\end{array}$ & 28 \\
\hline Fishing Industry & 3 & Organic production & 0 & Drinks industry & 2 & Tourism & 2 & R\&D & 26 \\
\hline Food waste & 3 & Prices_consumer & 0 & Fairtrade & 2 & Fairtrade & 1 & Fairtrade & 24 \\
\hline Grow your own & 3 & Prices_-producer & 0 & $\begin{array}{l}\text { Product market- } \\
\text { direct sales }\end{array}$ & 2 & Food packaging & 1 & Drinks industry & 19 \\
\hline Prices-producer & 3 & $\begin{array}{l}\text { Product market- } \\
\text { direct sales }\end{array}$ & 0 & $\begin{array}{c}\text { Product market- } \\
\text { exports }\end{array}$ & 2 & Grow your own & 1 & Prices_producer & 16 \\
\hline Food packaging & 2 & $\begin{array}{l}\text { Product market- } \\
\text { supermarkets }\end{array}$ & 0 & School \& hospital meals & 2 & Organic production & 1 & Traceability & 16 \\
\hline Fairtrade & 0 & Tourism & 0 & Grow your own & 1 & Fishing Industry & 0 & $\begin{array}{c}\text { Product market- } \\
\text { exports }\end{array}$ & 14 \\
\hline
\end{tabular}


The social dimension was a particularly strong theme in the opinions offered by farm sector respondents. It focused on two aspects: that of diet and nutrition and health, and the related need for greater child and adult education in relation to food and healthy eating, as well as the promotion of healthy eating and diet; and, the importance of, and support for, rural businesses and the role of agriculture in the survival of local, small communities-both in assisting food access and providing/supporting local economic activity. In a majority of cases the remarks on this latter aspect were set in a very negative context- "farming as we know it is long gone" (anonymous respondent). Ageing farmers, lack of succession, poor livability of farming communities-were all given as influences which threaten the social sustainability of farming. Overall, livability in farming communities, defined as " a statement of desires related to the contentment with life in a particular location of an individual or set of individuals" [17], could be seen as decreasing over time when taking into account the negative remarks present in the farmers' responses and positive reminiscences about the past.

The economic dimension in the respondents' comments stressed the importance of continued support for farming (notably financial support) to their survival. An integral part of farming's survival was the maintenance of a competitive processing sector which could maintain a demand for farming's products and enhance the distinctiveness of Scottish farm and food products. Also, frequently noted were the significance of food to the support of tourism (and vice versa), and the importance of Scottish producers being able to access and supply public sector organizations. Other market issues, especially profit distribution and supermarkets' power in the supply chain, featured strongly in the responses. Farmers largely appreciated the importance of fulfilling consumer requirements, but felt that they have very little direct influence on the market place.

The environmental aspects of agricultural production were widely appreciated by primary producers with support for environmentally friendly practices much in evidence and expressed in terms of carbon footprints, food miles and climate change, as well as an appreciation of the environmental and social benefits of organic farming. These concerns prevailed over those for the ecological quality of land as impacted by agricultural production. Although issues related to soil, air and land use featured in the respondents' comments, there was more focus on both the views of the public on farming practices and government regulation (mostly referring to the fear of "more red tape"). It is important however, to note that there is likely to be a significant group of farmers who are pursuing environmental issues due to their personal ethical values, rather than public and government pressure [18].

\subsection{Food Processors and Their Organizations}

Responses from food processors emphasized distinctive sectoral issues-e.g., meat processors highlighted issues related to hygiene and safety, food scares, public scrutiny and pressure groups. Barley and potato processing companies, on the other hand, mentioned the genetic modification of products (GM) and the access required to technological progress for maintaining competitiveness. Many of the comments and common themes were associated with low margins and long term contractual uncertainty, regardless of the profile of the processing sector concerned.

The economic dimension was of major importance, with the potential for expanding food production in Scotland and the significance of the drinks industry (whisky is Scotland's major food and 
drink export earner) both emphasized. The economic pressures on food processors were also evident as their low margins expose them to any drastic changes in price and supply availability. The lack of institutional "buffers" that could counteract such market and supply-related crises was also mentioned, especially by meat and dairy processing companies. Similar to farmers, respondents in this group also remarked that the spatial (geographical) distribution of food processing establishments does not serve primary supply well, especially in the meat sector. Geographical distance was also mentioned as an obstacle in relation to market access and the food transportation costs faced, especially by smaller food manufacturers.

The social sustainability dimension again reflected a concern for improved diet and nutritional intake amongst Scottish consumers, as well as improved health promotion and food education, but with respondents drawing attention to their own company's efforts in these areas. The responses of food processors also had a strong social capital orientation. According to the food processors, the quality and availability of skilled labor and middle management is scarce. Also, the level of training and vocational education does not correspond with the needs of the Scottish food industry. Simultaneously, there was a positive reflection on the abilities of Scottish primary producers and tradition in the delivery of quality raw materials, as well as on the revival of traditional Scottish food recipes and technologies. These were seen as strengths that could be used to support and diversify food offerings from Scotland in response to both short term food market fads/fashions, and also as a long term opportunity to build business and food quality reputation.

Environmental concerns were not so strongly articulated as most Scottish food processors have to comply with strict UK and EU legislation and industry regulations on both food safety and environmental protection. All responding processors recognized that a better allocation of resources is required in order to achieve the long term sustainable use of the natural means of production and a reduction of inputs. On the other hand, there were high expectations for both institutional support on "know-how" and also "grant-aid" for those companies that are not able to cope with high capital demands when introducing new environment friendly technologies.

\subsection{Retailers and Their Organizations}

Responses from retailers were focused on country of origin loyalty; trying to assure policy makers that fair priced and quality food is available on their shelves in Scotland, and that it is meaningfully labeled. They also underlined their commitment to local food sourcing, embracing both Scottish products and those from regional or even locality suppliers. In only two responses were there serious reservations expressed in relation to the profitable supply of local food within multiple networks. The cost of supplying local food in these two cases was mentioned in the context of ever-escalating competition in the UK and opportunities for sourcing cheaply abroad. In multiple retailers' responses, the negative focus was mostly related to environmental regulations and a technical inability to deal with their strict demands in a short period of time. In all but one response by multiple retailers, there was a clear commitment to procurement and sales of Scottish food in Scotland.

The social aspect of sustainability was visible mainly in mentions of the need for education and conscientious consumer food choice, which is facilitated by informative food labeling. Positive terms were used to underline a need for society's development in purchasing healthy food and promoting 
responsible food and drink consumption. Retailers gave numerous examples of cases where they were supporting both local supply of fresh and healthy food and enhancing favorable consumption trends.

With respect to economic sustainability, alongside an expressed desire to work collaboratively with suppliers (the issue of multiple retailer-supplier relationships is one of considerable public and political concern in the UK [19]), there was recognition of the importance of a high quality supply base in Scotland, both at the farming and processing levels. In the case of the latter, the maintenance of a continued supply of high quality labor was seen as vital with appropriate training opportunities being provided. An association of independent retailers, operating on a much smaller scale, expressed a concern about local food sourcing as being economically unviable in some cases. Overall, retailers had a positive view of market performance and the continuity of supply of Scottish food for Scottish markets and export. They also shared a view that the quality of Scottish food is a guarantor of its sustainability.

Environmental sustainability issues were visible in corporate level, strategic initiative examples, as well as in descriptions of future plans to counteract the negative impact of long distance food procurement and transport. Negative comments were related to a lack of directed co-ordination within the food sector and an uncertain regulatory future. Environmental problem areas such as food waste, climate change and irresponsible consumption of energy were noted, but framed positively in terms of future solutions and expected results. Emphasis was placed on the proactive stance of retailers as the driving force of the food supply chain, providing standards and setting an example to follow. Suppliers' involuntary compliance with these requirements was mentioned as a condition for long term co-operation and achievement of competitive advantage over rival retailers, not only in Scotland but also in the EU and beyond its borders.

\subsection{Industry Organization Responses}

The responses included 10 from industry organizations which represent a complete sectoral part of the agri-food system (e.g., for a particular product such as meat) or regulate the whole food chain (e.g., on food safety). The responses of these organizations reflected those of the businesses in the agri-food supply chain. Thus their comments emphasized the importance of encouraging and enabling a healthy diet (e.g., through education, food labeling and health promotion) and the contribution of their memberships to these issues, as well as the contribution of their members to the Scottish economy and society as a whole.

\subsection{Individual Responses-Consumers}

Amongst the plentiful responses by consumers, the social issues of diet and nutrition, health promotion, local food and its contribution to the local economy, and education in schools were by far the most commonly raised issues. Three of these topics - diet and nutrition, health promotion and education-were frequently raised in a negative manner, with criticism of government policy, the education system, business and society in relation to these issues. Shortcomings in the education system with respect to food, its production, preparation and contribution to good health, leading to an inability to make informed choices about food, were particularly strongly voiced. In contrast, a strong positive emphasis was placed on local food through cited benefits to the local economy, food quality 
and access. Food affordability, prices of local food and food access were mentioned frequently in the context of impoverished and remote communities. The "food citizen" ("food citizenship" has been defined as the practice of engaging in food-related behaviors -defined narrowly and broadly- that support, rather than threaten, the development of a democratic, socially and economically just, and environmentally sustainable food system [20], p. 271) responses were largely negative, criticizing the present food market situation and indicating specific needs and actions to be undertaken by both government and food businesses.

Economic sustainability was most commonly raised in relation to the maintenance of Scottish agriculture, the quality of its production and its essential natural resources. A similar, but less widespread concern was evident for the future of the fishing industry. Respondents were also concerned about the physical distribution of food and the adequacy of Scottish production and supplies. Altruistic concerns about the wellbeing of Scottish society were accompanied by fears of supermarket domination of the food market, and a lack of self sufficiency in food production resulting from the high share of imported food in the Scottish market. In the context of the latter point, respondents were strongly in favor of strengthening opportunities for the Scottish food and drink industry to supply public sector establishments.

Social sustainability concerns pertained mostly to the negative impact of diet on the health of both specific social groups and the whole of Scottish society. Responses underlining such issues were characterized by strong emotive expressions. School education, the involvement of retailers in the promotion of healthy food, and the control of advertising, especially for fast food chains, were other common themes. Another significant theme related to the sustainability of farming and rural communities, and Scottish traditional food production and preparation methods. On the other hand, some consumers expressed a lack of trust in relation to individual actors in the supply chains, notably supermarkets and farmers.

Environmental aspects mentioned by individual respondents can be divided into three major categories: climate change and eco-efficiency; animal welfare issues; environmentally friendly production (including organic farming), food safety and GM foods. There was a strong affective charge within statements, and high involvement of the self-selecting respondents, especially mentioning animal rights issues and GM foods. Local food production and distribution was seen as having a positive impact on the environment and biodiversity, and was also raised in the context of food freshness and good quality. There were also specific expectations for the development of sustainable technologies for important Scottish foods, especially salmon farming and game meats.

\subsection{Geographical Pattern of Responses}

The geographical distribution of responses by topic and region is shown in Table 3 (for a brief description of the Scottish regions see Note 1 of Table 1). It summarizes the views of respondents who live in Scotland and also from those respondents living outside Scotland, or who did not identify their location. First, it should be noted that there was considerable similarity in the pattern of responses across Scotland. Diet and nutrition was the most frequently cited issue across the regions with the exception of the North West where it was second in frequency. Allied to this concern for diet, health and wellbeing were high levels of concern for health promotion and school education of food issues. 
Local food and its contribution to local economies was also well to the fore in the responses from all regions, and was the most frequent of all topics mentioned in the North West. Not surprisingly respondents from this very rural region were also concerned for the continuation of farming, as well as the importance of local food producers in supplying their communities with food.

A further observation is that social sustainability topics dominate the issues raised in each of the regions; in all four areas eight of the ten most frequently cited topics were aspects of social sustainability. To some extent this reflects the fact that the majority of respondents were individual citizens/consumers. The top economic topic in all regions concerned the maintenance of farming. Amongst the environmental sustainability topics, the universally most frequently raised topic was that of environmentally friendly food production with organic production placed second in all regions except the North West. The pattern of responses from those respondents from outside Scotland reflected those of Scottish residents.

\subsection{Supply Chain Businesses and Citizen Consumers-Views Compared}

Examination of the most frequently raised topics by supply chain businesses and their organizations, as compared to those of consumer citizens reveals some interesting points. For consumers there is a very strong presence of social concerns in their responses. Eight out of the top ten topics are all primarily of a social sustainability nature, including the top six. The primary economic concern is for the future of Scottish agriculture itself and the element of food security that a sound domestic farming sector provides, whilst the foremost environmental concern is for environmentally friendly agriculture and food processing. In contrast, whilst supply chain businesses and their organizations have the same top three concerns as consumers (diet and nutrition, local food and local economies and health promotion), they reflect, as might be expected, far more economic sustainability concerns in their responses. Indeed, four of the top ten for these respondents are economic in nature: the maintenance of a farming industry which will ensure agricultural products for the food supply chain; the maintenance of a competitive processing industry with suitable infrastructure; the provision of an adequately skilled workforce; and the collaboration necessary to ensure effective, efficient and sustainable food supply. Finally, whilst the wide-ranging concern for environmentally friendly food production was well to the fore for both businesses and consumers, more specific environmentally sustainability issues were further down the list of those raised. 
Table 3. Rankings of topic areas by region (blue $=$ economic, green $=$ environmental and red $=$ social) .

\begin{tabular}{|c|c|c|c|c|c|c|c|c|c|}
\hline \multicolumn{2}{|l|}{ North West } & \multicolumn{2}{|l|}{ North East } & \multicolumn{2}{|l|}{ South East } & \multicolumn{2}{|l|}{ South West } & \multicolumn{2}{|l|}{ Other } \\
\hline Topic areas & Cases & Topic areas & Cases & Topic areas & Cases & Topic areas & Cases & Topic areas & Cases \\
\hline $\begin{array}{l}\text { Local food \& } \\
\text { local economies }\end{array}$ & 40 & Diet and nutrition & 31 & Diet and nutrition & 116 & Diet and nutrition & 87 & Diet and nutrition & 25 \\
\hline Diet and nutrition & 39 & Education in schools & 23 & $\begin{array}{c}\text { Local food \& } \\
\text { local economies }\end{array}$ & 81 & Education in schools & 59 & $\begin{array}{c}\text { Local food \& } \\
\text { local economies }\end{array}$ & 22 \\
\hline Farming industry & 26 & Health promotion & 20 & Health promotion & 70 & Health promotion & 59 & Health promotion & 20 \\
\hline Education in schools & 24 & $\begin{array}{c}\text { Local food \& } \\
\text { local economies }\end{array}$ & 18 & $\begin{array}{l}\text { Environmentally friendly } \\
\text { food production }\end{array}$ & 67 & $\begin{array}{c}\text { Local food \& } \\
\text { local economies }\end{array}$ & 57 & $\begin{array}{c}\text { Food and } \\
\text { drink advertising }\end{array}$ & 18 \\
\hline Health promotion & 23 & Access to food & 15 & Access to food & 66 & Access to food & 54 & $\begin{array}{l}\text { Environmentally friendly } \\
\text { food production }\end{array}$ & 15 \\
\hline $\begin{array}{c}\text { Local food \& } \\
\text { local communities }\end{array}$ & 23 & Adult education & 14 & Farming industry & 62 & Adult education & 51 & Food labelling & 14 \\
\hline Access to food & 21 & $\begin{array}{c}\text { School \& } \\
\text { hospital meals }\end{array}$ & 11 & Adult education & 60 & $\begin{array}{c}\text { Local food \& } \\
\text { local communities }\end{array}$ & 46 & Farming industry & 13 \\
\hline Adult education & 18 & $\begin{array}{l}\text { Environmentally friendly } \\
\text { food production }\end{array}$ & 10 & Education in schools & 56 & $\begin{array}{l}\text { Environmentally friendly } \\
\text { food production }\end{array}$ & 38 & Access to food & 12 \\
\hline $\begin{array}{c}\text { School \& } \\
\text { hospital meals }\end{array}$ & 17 & Farming industry & 10 & Food labelling & 51 & $\begin{array}{c}\text { School \& } \\
\text { hospital meals }\end{array}$ & 38 & Adult education & 12 \\
\hline $\begin{array}{l}\text { Product market- } \\
\text { supermarkets }\end{array}$ & 16 & Food labelling & 10 & $\begin{array}{c}\text { Local food \& } \\
\text { local communities }\end{array}$ & 51 & Farming industry & 34 & Education in schools & 12 \\
\hline Food labelling & 15 & Organic production & 9 & $\begin{array}{c}\text { School \& } \\
\text { hospital meals }\end{array}$ & 42 & Food labelling & 32 & $\begin{array}{c}\text { Labour market- } \\
\text { skills, jobs }\end{array}$ & 11 \\
\hline Grow your own & 15 & $\begin{array}{l}\text { Product market- } \\
\text { public sector }\end{array}$ & 9 & Prices - consumer & 41 & Grow your own & 30 & $\begin{array}{l}\text { Food Chain } \\
\text { Collaboration }\end{array}$ & 9 \\
\hline $\begin{array}{l}\text { Processing capacity } \\
\text { in Scotland }\end{array}$ & 15 & Grow your own & 8 & Food and drink advertising & 38 & Organic production & 24 & $\begin{array}{l}\text { Processing capacity } \\
\text { in Scotland }\end{array}$ & 9 \\
\hline $\begin{array}{l}\text { Product market- } \\
\text { public sector }\end{array}$ & 15 & $\begin{array}{l}\text { Labour market- } \\
\text { skills, jobs }\end{array}$ & 8 & Grow your own & 38 & $\begin{array}{c}\text { Food and } \\
\text { drink advertising }\end{array}$ & 23 & $\begin{array}{c}\text { External factors } \\
\text { affecting food supply }\end{array}$ & 8 \\
\hline
\end{tabular}


Table 3. Cont.

\begin{tabular}{|c|c|c|c|c|c|c|c|c|c|}
\hline \multicolumn{2}{|l|}{ North West } & \multicolumn{2}{|l|}{ North East } & \multirow{2}{*}{$\begin{array}{c}\text { South East } \\
\text { Topic areas }\end{array}$} & \multicolumn{3}{|c|}{ South West } & \multicolumn{2}{|l|}{ Other } \\
\hline Topic areas & Cases & Topic areas & Cases & & Cases & Topic areas & Cases & Topic areas & Cases \\
\hline $\begin{array}{l}\text { Environmentally friendly } \\
\text { food production }\end{array}$ & 14 & $\begin{array}{l}\text { Product market- } \\
\text { supermarkets }\end{array}$ & 8 & $\begin{array}{l}\text { Food Chain } \\
\text { Collaboration }\end{array}$ & 34 & $\begin{array}{l}\text { Local food \& } \\
\text { food miles }\end{array}$ & 23 & Food waste & 8 \\
\hline $\begin{array}{c}\text { Food and } \\
\text { drink advertising }\end{array}$ & 14 & $\begin{array}{c}\text { External factors } \\
\text { affecting food supply }\end{array}$ & 7 & $\begin{array}{l}\text { Product market- } \\
\text { public sector }\end{array}$ & 34 & $\begin{array}{l}\text { Product market- } \\
\text { public sector }\end{array}$ & 23 & R\&D & 8 \\
\hline $\begin{array}{l}\text { Local food \& } \\
\text { food miles }\end{array}$ & 14 & Fishing Industry & 7 & Organic production & 33 & Food packaging & 22 & Food packaging & 7 \\
\hline $\begin{array}{l}\text { Product market- } \\
\text { direct sales }\end{array}$ & 14 & $\begin{array}{l}\text { Local food \& } \\
\text { food miles }\end{array}$ & 7 & Food waste & 32 & $\begin{array}{l}\text { Product market- } \\
\text { supermarkets }\end{array}$ & 21 & Food safety & 7 \\
\hline Organic production & 13 & $\begin{array}{c}\text { Food and } \\
\text { drink advertising }\end{array}$ & 6 & $\begin{array}{c}\text { Product market- } \\
\text { supermarkets }\end{array}$ & 31 & Animal welfare & 19 & $\begin{array}{l}\text { Local food \& } \\
\text { food miles }\end{array}$ & 7 \\
\hline Animal welfare & 12 & $\begin{array}{c}\text { Local food \& } \\
\text { local communities }\end{array}$ & 6 & $\begin{array}{c}\text { Labour market- } \\
\text { skills, jobs }\end{array}$ & 29 & Food miles (other) & 19 & $\begin{array}{c}\text { Local food \& } \\
\text { local communities }\end{array}$ & 7 \\
\hline Fishing Industry & 10 & Food packaging & 5 & $\begin{array}{l}\text { Local food \& } \\
\text { food miles }\end{array}$ & 29 & $\begin{array}{l}\text { External factors } \\
\text { affecting food supply }\end{array}$ & 18 & Organic production & 7 \\
\hline Food waste & 10 & Food waste & 5 & Food safety & 28 & Prices - consumer & 18 & $\begin{array}{c}\text { School \& } \\
\text { hospital meals }\end{array}$ & 7 \\
\hline Prices-consumer & 10 & $\begin{array}{l}\text { Product market- } \\
\text { direct sales }\end{array}$ & 5 & Food miles (other) & 25 & $\begin{array}{l}\text { Product market- } \\
\text { direct sales }\end{array}$ & 18 & Traceability & 7 \\
\hline Tourism & 10 & R\&D & 5 & $\begin{array}{c}\text { Processing capacity } \\
\text { in Scotland }\end{array}$ & 25 & Food waste & 17 & Animal welfare & 6 \\
\hline $\begin{array}{c}\text { Capacity for } \\
\text { food production }\end{array}$ & 9 & $\begin{array}{l}\text { Capacity for food } \\
\text { production }\end{array}$ & 4 & $\begin{array}{c}\text { External factors } \\
\text { affecting food supply }\end{array}$ & 24 & $\begin{array}{c}\text { Labour market- } \\
\text { skills, jobs }\end{array}$ & 17 & Food miles (other) & 6 \\
\hline $\begin{array}{l}\text { Food Chain } \\
\text { Collaboration }\end{array}$ & 9 & $\begin{array}{l}\text { Food Chain } \\
\text { Collaboration }\end{array}$ & 4 & Animal welfare & 23 & $\begin{array}{c}\text { Processing capacity } \\
\text { in Scotland }\end{array}$ & 16 & $\begin{array}{c}\text { Product market- } \\
\text { supermarkets }\end{array}$ & 6 \\
\hline Food miles (other) & 9 & Food safety & 4 & $\mathbf{R} \& \mathbf{D}$ & 23 & Fishing Industry & 14 & $\begin{array}{c}\text { Capacity for } \\
\text { food production }\end{array}$ & 5 \\
\hline
\end{tabular}


Table 3. Cont.

\begin{tabular}{|c|c|c|c|c|c|c|c|c|c|}
\hline \multicolumn{2}{|l|}{ North West } & \multicolumn{2}{|l|}{ North East } & \multicolumn{2}{|l|}{ South East } & \multicolumn{2}{|l|}{ South West } & \multicolumn{2}{|l|}{ Other } \\
\hline Topic areas & Cases & Topic areas & Cases & Topic areas & Cases & Topic areas & Cases & Topic areas & Cases \\
\hline $\begin{array}{l}\text { External factors } \\
\text { affecting food supply }\end{array}$ & 8 & Prices-consumer & 4 & Tourism & 22 & Food safety & 14 & Prices - consumer & 5 \\
\hline Food packaging & 8 & $\begin{array}{c}\text { Processing capacity } \\
\text { in Scotland }\end{array}$ & 4 & Food packaging & 21 & $\begin{array}{l}\text { Food Chain } \\
\text { Collaboration }\end{array}$ & 12 & $\begin{array}{c}\text { Product market- } \\
\text { exports }\end{array}$ & 5 \\
\hline Food safety & 8 & Animal welfare & 3 & Fishing Industry & 17 & $\begin{array}{c}\text { Capacity for } \\
\text { food production }\end{array}$ & 10 & Drinks industry & 4 \\
\hline Fairtrade & 7 & Food miles (other) & 3 & $\begin{array}{l}\text { Product market- } \\
\text { direct sales }\end{array}$ & 17 & Tourism & 10 & Fishing Industry & 4 \\
\hline $\begin{array}{c}\text { Labour market- } \\
\text { skills, jobs }\end{array}$ & 6 & Prices_producer & 3 & $\begin{array}{c}\text { Capacity for } \\
\text { food production }\end{array}$ & 16 & Drinks industry & 7 & $\begin{array}{l}\text { Product market- } \\
\text { public sector }\end{array}$ & 4 \\
\hline Prices-producer & 6 & Traceability & 3 & Drinks industry & 16 & Fairtrade & 7 & Tourism & 4 \\
\hline Traceability & 5 & Drinks industry & 2 & Traceability & 13 & R\&D & 6 & Prices_producer & 3 \\
\hline $\begin{array}{c}\text { Product market- } \\
\text { exports }\end{array}$ & 4 & $\begin{array}{c}\text { Product market- } \\
\text { exports }\end{array}$ & 2 & Fairtrade & 11 & Traceability & 6 & Grow your own & 2 \\
\hline $\mathbf{R} \& \mathbf{D}$ & 4 & Tourism & 2 & $\begin{array}{c}\text { Product market- } \\
\text { exports }\end{array}$ & 11 & Prices-producer & 5 & Fairtrade & 1 \\
\hline Drinks industry & 3 & Fairtrade & 1 & Prices-producer & 8 & $\begin{array}{c}\text { Product market- } \\
\text { exports }\end{array}$ & 5 & $\begin{array}{l}\text { Product market- } \\
\text { direct sales }\end{array}$ & 1 \\
\hline
\end{tabular}




\subsection{Policy Implications}

The wide variety of actors within the food supply chain, and the many and varied views that they hold in relation to sustainability issues, presents a challenge for policy development with respect to securing a sustainable food system. The divergence of views and priorities on sustainability should be recognized if policy is to succeed. Whilst it may not be crucial to policy success in areas of regulatory enforcement with a strong evidence base, it is likely to be very important where Government seeks to change behavior through engaging with stakeholders and their organizations to encourage and enable behavioral change. Moreover, any policy implications of the current analysis have to be viewed within the overarching purpose of the Scottish Government: "to focus government and public services on creating a more successful country with opportunities for all of Scotland to flourish through increasing sustainable economic growth" (p. vii) [21], as well as its five related strategic objectives: wealthier and fairer; healthier; safer and stronger; smarter; and greener.

Whilst environmental sustainability is frequently foremost in the political sustainability agenda, the importance of social sustainability is strongly evident in the foregoing analysis. For concerned "food citizens" this is understandable, but it also runs through the collective psyche of Scottish food businesses. To some extent this is because concern about the Scottish diet has been on the Scottish political agenda food since at least 1993 when the Scottish Diet Report [22] revealed the extent of Scotland's poor diet and its adverse impact on health. Since that time there have been a number of initiatives aimed at addressing the problem but with little success. As 'Choosing the Right Ingredients-The future for Food in Scotland' [2] notes "Our poor diet contributes to high obesity levels and is a cause of major chronic diseases, costing the National Health Service hundreds of millions of pounds every year. Poor health means a poor quality of life for individuals, lost productivity for employers and distress for families caring for chronically sick relatives. Most importantly, a poor diet can shorten life expectancy" (p. 8). The concern of food businesses on this issue may be due to political awareness and sensitivity, and a perceived need to be saying the right things, but it will also relate strongly to economic sustainability through the enhanced market performance that 'healthier' products may bring. Given this context, the analysis suggests the following areas as important for food policy development.

Diet and nutrition-encouraging healthy food choices. A clear finding is the widespread identification of the interplay between food, diet and health and the need for greater promotion and education with respect to health and food. Concern for this matter runs from the farming sector where there is apprehension about a lack of understanding of farming and food, through to retailers with their concern for food related education and assisting favorable, healthy food consumption trends. At the same time, consumers themselves recognize the negative impact of a poor diet and the need for adult and child education with respect to food and health. Policy in this area needs to be multifaceted, addressing not only consumer behavior with respect food choice, but also lifestyle issues and the conduct of the food industry with respect to food promotion and food content.

The importance of local food. Local food, and the many issues that it involves, was well to the fore in the responses of all stakeholder groups. For consumers there is a strong favorable attitude towards local food and local food production, and a concern that such food should be accessible (assisting equity between socioeconomic groups). Local food is seen as important for maintaining farming, 
generating local employment and income, its favorable consumption attributes, and as an important component of food security in its widest sense. Processors value the quality and traditions of Scottish food and see it as a basis for building business activity and reputation. Similarly, retailers have favorable views in relation to Scottish food and its supply, whilst recognizing the commercial importance of local food sourcing and provision (from both the aspects of consumer appeal and the logistics of food procurement). Policies which recognize the multi-dimensional value of local food systems would appear to be able to deliver sustainability benefits on several fronts.

Building sustainability on sound economic performance. Concern for sustainability and its many high profile aspects - such as carbon footprints, waste reduction, food mile reduction, and greater efficiency in energy use - is evident in the responses of all stakeholder groups. Thus the importance of sustainability, and particularly concern for environmental sustainability, as part of the requirement to achieve intergenerational equity, is universally recognized. For businesses, however, this is commonly associated with cost savings (e.g., reduced energy use or waste), public image or market positioning; which are all strongly related to economic performance [14,23,24]. Not surprisingly, there is a predominant concern with economic sustainability amongst business stakeholders. For primary producers and processors, this centers on profits, prices and subsidies for farmers, whilst for retailers it relates to remaining competitive whilst complying with regulatory requirements. One implication of this finding is that beyond those farmers and businesses which have a strong ethical drive to operate with great social and environmental concern, social and environmental sustainability needs to be built upon sound economic performance. Moreover, legislation which seeks to gain greater social or environmental sustainability may under-deliver if businesses regard it as detrimental to their competitiveness and long term economic sustainability. This will be particularly the case for policies which seek to exemplify and encourage environmental and social sustainability without a financial reward. However, environmental sustainability may also be furthered by financial support for environmentally friendly investment or where it is tied to good environmental practices.

Supermarkets: market power, collaboration and sustainability. A major equity issue to arise relates to the power of the supermarkets. This power and dominance featured strongly in the responses of both farmers and consumers. Processors concerns took a slightly different form, being expressed in terms of low margins and contractual uncertainty. However, supermarkets are clearly the dominant players or leaders of their supply chains and as such have the ability to direct positive changes with respect to environmental and social sustainability. The importance of such issues in their strategic pronouncements provides a basis for encouraging collaborative activity with their suppliers, not only to secure commercial benefit for those concerned, but in the longer term on the other dimensions of sustainability as well. Thus policy needs to recognize the primacy of economic concerns, and to seek whole chain and collaborative approaches to improving food chain sustainability.

Regulation and support in building human and technical capabilities. Across food supply businesses there is a common need for support and encouragement in developing capabilities with respect to sustainability. Greater environmental regulation requires new knowledge, skills and business systems, which necessitates appropriate education and training, whilst enhanced technical capabilities will normally require financial investment. 


\section{Conclusions}

The results of this research aim to support coherent strategic approaches that take into account trade-offs which address the conflicting needs of stakeholders, food related communication and education requirements, as well as regulatory and legislative efforts to enhance all facets of sustainability in the Scottish food supply chain.

An interesting observation arising from the National Food Policy discussion was the willingness of food and drink sector stakeholders to engage so strongly in the process of policy development. As the discussion focused strongly on Scotland and Scottish society, the stakeholders' statements included broad perspectives of problems and challenges, perceived solutions, articulated opportunities and conditions for their realization. A vast array of factors in the macro- and microenvironment were mentioned, very often in the light of individual cases and specific examples. Actors in the supply chain expressed their views on the role of government and other institutions in ensuring the sustainability of food and drink production and distribution in Scotland. National pride, knowledge, quality of resources and tradition were often indicated as possible sources of competitive advantage. On the other hand, wasted opportunities and a lack of interest or understanding by decision makers were sources of frustration for respondents. There were common interests within and between stakeholder groups, but also visible were the areas of conflict of various origins (e.g., consumers were generally against the introduction of GM products whilst in contrast, producers favored the controlled introduction so as assist productivity improvement). Also, the responses to the discussion were often seen by the stakeholders as an opportunity to indicate where reality falls short of their expectations.

When applying a broad sustainability framework it is clear that Scottish food chain actors are largely concerned with the current state of affairs and prospects for the food sector. The two of them are intertwined in the responses and there is a collective consensus that economic success is required to ensure food sector development and the survival not only for businesses, but communities around Scotland as well. The resilience of food supply systems is seen as important in developing high potential consumer markets, which thanks to education and responsible consumption behavior could provide dynamic and progressive demand for food that can be supplied by sustainable food production and distribution methods.

The question arises as to whether such a wealth of facts, thoughts and opinions, as well as emotions, could be used to aid the direction of food policy? Undoubtedly, each sector in the food industry requires particular decisions that could enhance its sustainability by tackling specific challenges. However, common issues faced by the farming sector, food processing and distribution, as well as consumers, should be addressed in a way that benefits Scottish society at large. A further requirement for policy development is to gain a better understanding of where clear complementarities exist between the different dimensions of sustainability, for example where the pursuit of economic sustainability may also serve environmental sustainability (such as waste reduction which leads to decrease costs). In such situations, sustainability may be primarily driven by commercial considerations and the role of policy may be purely to facilitate the process or "to leave well alone". In other cases, where clear conflicts exist, more forceful policy interventions may be needed. These are areas to which the authors' research has now turned. 


\section{Acknowledgements}

This paper was funded as part of research commissioned by the Scottish Government Rural and Environment Research and Analysis Directorate (RERAD). We would like to thank the comments received from Kathy Johnston and her team during the development of the project. However, the opinions presented in this paper are sole responsibility of the authors.

\section{References}

1. Scottish Parliament. Food Policy. Official Report. 7 November 2007. Available online: http://www.scottish.parliament.uk/business/officialreports/meetingsparliament/or-07/sor1107-02.htm (accessed on 10 January 2011).

2. Scottish Government. Choosing the Right Ingredients-the Future for Food in Scotland; The Scottish Government: Edinburgh, UK, 2008.

3. Scottish Government. Recipe for Success-Scotland's National Food and Drink Policy; The Scottish Government: Edinburgh, UK, 2009.

4. Van Calker, K.J.; Betentsen, P.B.M.; Giesen G.W.J. Maximising sustainability of Dutch dairy farming systems for different stakeholders: A modelling approach. Ecolog. Econ. 2007, 58, 1-13.

5. Van Calker, K.J.; Berentsen, P.B.M.; Romero, C.; Giesen, G.; Huirne, R.B.M. Development and application of a multi-attribute sustainability function for Dutch dairy farming systems. Ecolog. Econ. 2006, 57, 640-658.

6. Bunn, M.; Savage, G.; Holloway, B. Stakeholder analysis for multi-sector innovations. J. Bus. Mark. 2002, 17, 181-203.

7. Yakovleva, N. Measuring the sustainability of the food supply chain: A case study of the UK. J. Environ. Plan. Manage. 2007, 9, 75-100.

8. Reynolds, N.; Fischer C.; Hartmann M. Determinants of sustainable business relationships in selected German agri-food chains. Brit. Food J. 2009, 111, 776-793.

9. Felzensztein, S.; Huemer, L.; Gimmon, E. The effects of co-location on marketing externalities in the salmon-farming industry. J. Bus. Mark. 2010, 25, 73-82.

10. United Nations World Commission on Environment and Development. Our Common Future; Oxford University Press: Oxford, UK, 1987.

11. European Commission-Agriculture Directorate-General. A Framework for Indicators for the Economic and Social Dimensions of Sustainable Agriculture and Rural Development, 5 February 2001. Available online: http://ec.europa.eu/agriculture/publi/reports/sustain/index_en.pdf (accessed on 11 January 2011).

12. Forestry Commission of Great Britain. Sustainability. 2011. Available online: http://www.forestry.gov.uk/ forestry/edik-59fmzf (accessed on 11 January 2011)

13. Brown, O.; Sander, C. Supermarket Buying Power: Global Supply Chains and Smallholder Farmers; International Institute for Sustainable Development: Winnipeg, Canada, 2007.

14. Jones, P.; Comfort, D.; Hillier, D. What's in store? Retail marketing and corporate social responsibility. Mark. Intel. Plan. 2007, 25, 17-30. 
15. Leat, P.; Kupiec-Teahan, B.; Revoredo-Giha, C.; Lamb, D.; Hughes, P.; Moxley, A. The Future for Food in Scotland Analysis of Responses to the National Discussion; Scottish Government: Edinburgh, UK, 2008.

16. Gabzdylova, B.; Raffensperger, J.F.; Castka, P. Sustainability in the New Zealand wine industry: drivers, stakeholders and practices. J. Cleaner Prod. 2009, 17, 992-998.

17. De Chazal, J. A systems approach to livability and sustainability: Defining terms and mapping relationships to link desires with ecological opportunities and constraints. Sys. Res. Behav. Sci. 2010, 27, 585-597.

18. Fairweather, J.R.; Rosin, C.J.; Hunt, L.M.; Campbell, H.R. Are conventional farmers conventional? Analysis of the environmental orientations of conventional New Zealand farmers. Rural Soc. 2009, 74, 430-454.

19. UK Competition Commission. Groceries Market Investigation; Final Report; 2008. Available online: http://www.competition-commission.org.uk/rep_pub/reports/2008/538grocery.htm (accessed on 13 January 2011)

20. Wilkins, J.L. Eating right here: Moving from consumer to food. Agr. Human Values 2005, 22, 269-273.

21. Scottish Government. The Government Economic Strategy; the Scottish Government: Edinburgh, UK, 2009.

22. Scottish Office. Scotland's health a challenge to us all-The Scottish Diet; Report of a Working Party to the Chief Medical Officer for Scotland; HMSO: Edinburgh, UK, 1993. Available online: http://www.scotland.gov.uk/Resource/Doc/47060/0012960.pdf (accessed on 15 January 2011).

23. Quasi, A.M. Identifying the determinants of corporate managers' perceived social obligations. Manage. Decis. 2003, 41, 822-31.

24. Lockie, S. Capturing the sustainability Agenda: Organic foods and media discourses on food scares, environment, genetic engineering, and health. Agr. Human Values, 2006, 23, 313-323.

25. Scottish Government. Food and Drink: Key Sector Report; The Scottish Government: Edinburgh, UK, 2009.

26. Scottish Government. Food and Drink in Scotland: Key Facts 2010; The Scottish Government: Edinburgh, UK, 2010.

\section{Appendices}

Appendix 1-Brief description of the Scottish Food and Drink Sector

The Food and Drink Sector is a key sector of the Scottish Economy [25]. It not only comprises agriculture, fishing, and food and drink manufacturing but also encompasses a large supply chain that includes food and drink wholesaling, retailing and the food service sector.

According to the most recent figures in 2008 [26] the gross value added (GVA) of the food and drink supply chain was $£ 10.2$ billion (approximately $20 \%$ of the total Scottish GVA) with turnover of $£ 34.1$ billion. The supply chain was estimated to comprise 76,200 businesses - most of them very small firms (1-10 employees) — and employs approximately 369,200 persons across Scotland. 
GVA in the agricultural sector increased consistently during the period of 2001 to 2004 and then decreased sharply from $£ 1$ billion to $£ 0.6$ billion in 2005 . This was caused by a change in subsidies to the sector. Since 2005, GVA in agriculture increased to $£ 0.8$ billion in 2007 and then dropped to $£ 0.7$ billion in 2008. GVA in sea fishing increased from $£ 95$ million in 2001 to $£ 144$ million in 2008. Similarly, GVA in all four sectors of the food and drink industry (i.e., manufacturing, wholesaling, retailing and non-residential catering) increased during the period of 2001-2008. The total GVA in the food and drink industry increased from $£ 6.4$ billion in 2001 to $£ 9.2$ billion in 2008.

There is no information about the sectoral composition of the food and drink supply chain GVA. As regards the Scottish agricultural sector, finished livestock and livestock products contributed 37\% and $14 \%$ respectively to the value of total agricultural output in 2009 ( $£ 2.261$ billion), cereals, horticulture and other crops contributed $11.1 \%, 10.6 \%$ and $9.4 \%$ respectively. Information about composition of food and drink manufacturing indicates that beverages accounted for $63 \%$ of the total GVA, followed by meat and fish processing each contributing $7 \%$.

Total sales of Scottish primary produce amounted to $£ 3.1$ billion in 2007 , of which $21 \%$ were purchased by Scottish processors and $20 \%$ by Scottish households. Non-Scottish purchasers accounted for $47 \%$ of the total sales and Scottish primary producers for $6 \%$.

The Scottish food and drink sector has a strong international reputation at the luxury end of the market, driven by whisky, salmon, seafood and beef, and enhanced by strong brands. In fact, overseas food and drink exports from Scotland are worth $£ 5$ billion a year. Whisky is the top exporter for Scotland. Overseas food exports are $£ 800$ million a year (fish and shellfish make up the largest proportion (55\%) of food exported overseas), while food imports from overseas are $£ 900$ million a year (approximately $58 \%$ from the rest of the EU). Fruits and vegetables are the sector with the largest trade balance deficit (£93 million in 2009).

As regards consumption patterns, data for 2008 indicate that meat accounted for $21 \%$ of Scottish consumer's total expenditure on food - the greatest share. Bread flour and cereal accounted for 13\%, whilst alcoholic drinks and milk, cheese and eggs each accounted for $11 \%$. Expenditure on fruit and vegetables was $15 \%$ and expenditure on fish was $5 \%$ of the total. 


\section{Appendix 2}

Table A-1. Explanation of each one of the categories used in the analysis.

\begin{tabular}{|c|c|}
\hline \multicolumn{2}{|l|}{ Economic dimension } \\
\hline Capacity for food production & $\begin{array}{l}\text { Capacity for expanding food production in Scotland given its climate and } \\
\text { natural amenities. Identification of types of food and drink that could be } \\
\text { produced most efficiently. }\end{array}$ \\
\hline Drinks industry & $\begin{array}{l}\text { Recognition of the drinks industry and its contribution to Scotland's } \\
\text { exports and economy, and its relationship with farming and tourism. }\end{array}$ \\
\hline $\begin{array}{l}\text { External factors } \\
\text { affecting food supply }\end{array}$ & $\begin{array}{l}\text { Issues external to the Scottish food and drink industry such as energy } \\
\text { prices, EU legislation and global markets. Also, climate change. }\end{array}$ \\
\hline Fairtrade & $\begin{array}{l}\text { Attitudes to fair trade goods, their pricing and availability, as well as their } \\
\text { origin and the terms of trade. }\end{array}$ \\
\hline Farming industry & $\begin{array}{l}\text { Maintenance of Scottish agricultural production and the quality of its } \\
\text { production, and protecting good agricultural land to ensure appropriate } \\
\text { food security. Includes significance of small scale production. }\end{array}$ \\
\hline Fishing Industry & $\begin{array}{l}\text { Maintenance of fish stock and a viable fishing industry, so as to maintain } \\
\text { fishing communities and fish as an important dietary constituent. Includes } \\
\text { fish farming. }\end{array}$ \\
\hline Food Chain Collaboration & $\begin{array}{l}\text { Food chain collaboration ensuring effective, efficient and sustainable food } \\
\text { supply which meets the needs of the businesses involved and consumers. }\end{array}$ \\
\hline Labor market—skills, jobs & $\begin{array}{l}\text { Provision of employment by the food and drink industry. Provision of } \\
\text { training to food and drink industry's employees. Attractiveness of sector as } \\
\text { a career choice. }\end{array}$ \\
\hline Prices-producer & $\begin{array}{l}\text { Commodity prices received by the producers for the inputs into food and } \\
\text { drink production. }\end{array}$ \\
\hline Processing capacity in Scotland & $\begin{array}{l}\text { The number and type of food processors and manufacturers in Scotland, } \\
\text { their sourcing and selling strategies and competitiveness issues. Includes } \\
\text { the provision infrastructure, including abattoirs and good transport links. } \\
\text { Requirement for cohesion / collaboration in enterprise development } \\
\text { support. }\end{array}$ \\
\hline Product market—direct sales & Food sold directly by producers, its prices and impact on farmers' income. \\
\hline Product market—exports & $\begin{array}{l}\text { Identification of overseas markets for Scottish food and drink products and } \\
\text { ways of expanding those. }\end{array}$ \\
\hline Product market—-public sector & $\begin{array}{l}\text { Scope for public procurement in providing Scottish food and drink } \\
\text { industry with opportunities to supply the local establishments. }\end{array}$ \\
\hline Product market—supermarkets & $\begin{array}{l}\text { Prices set by supermarkets, their market power and contribution to the } \\
\text { Scottish economy. }\end{array}$ \\
\hline $\mathrm{R} \& \mathrm{D}$ & $\begin{array}{l}\text { Product innovation as well as innovation in methods of growing of food, } \\
\text { its processing, storage and packaging. Also, R \& D relating to food science } \\
\text { and nutrition. Maintenance of agricultural productivity, including GMO } \\
\text { adoption. Plus Knowledge Transfer activities related to R\&D. }\end{array}$ \\
\hline Tourism & $\begin{array}{l}\text { The role and contribution of Scottish food to tourism industry and how } \\
\text { food policy can promote Scotland as a country to tourists. Catering sector } \\
\text { as it relates to tourism. }\end{array}$ \\
\hline
\end{tabular}


Table A-1. Cont.

\begin{tabular}{|c|c|}
\hline \multicolumn{2}{|l|}{ Environmental dimension } \\
\hline Animal welfare & $\begin{array}{l}\text { The condition of livestock in farms, animal disease and ethical } \\
\text { considerations. Plus welfare of animals in transit. }\end{array}$ \\
\hline $\begin{array}{l}\text { Environmentally friendly } \\
\text { food production }\end{array}$ & $\begin{array}{l}\text { The impact of agriculture and food processing on the environment in terms } \\
\text { of pollution, greenhouse gas emissions, energy consumption, land use and } \\
\text { waste. Includes concerns about GM production. }\end{array}$ \\
\hline Food miles (other) & $\begin{array}{l}\text { All other consideration in the food miles argument. For example, the } \\
\text { balance between food miles and energy intensity of local production. }\end{array}$ \\
\hline Food packaging & $\begin{array}{l}\text { Use of less packaging while still providing adequate food safety. Raising } \\
\text { awareness about recycling and provision of recycling facilities. }\end{array}$ \\
\hline Food waste & $\begin{array}{l}\text { Excess of food bought but not consumed by households, as well as waste } \\
\text { generated by the food supply chain. }\end{array}$ \\
\hline Local food \& food miles & $\begin{array}{l}\text { The impact of local production and consumption on the environment in } \\
\text { terms of the carbon footprint of the distance travelled by food. }\end{array}$ \\
\hline Organic production & $\begin{array}{l}\text { The costs and benefits of organic production (perceived and recognized) in } \\
\text { terms of health benefits, ethical issues and environmental impact. }\end{array}$ \\
\hline \multicolumn{2}{|l|}{ Social dimension } \\
\hline Access to food & $\begin{array}{l}\text { Location of supermarkets and other retail outlets in rural and urban areas, } \\
\text { formation of food deserts and public transport issues in such areas. } \\
\text { Availability of good quality food in deprived areas, and for disadvantaged } \\
\text { groups. Also, community food schemes. }\end{array}$ \\
\hline Adult education & $\begin{array}{l}\text { Provision of cooking guidance and information about food nutrition and } \\
\text { food production in places like community centers, and distribution of } \\
\text { information leaflets and brochures. Further and Higher Education in } \\
\text { relation to Food Science and Technology. }\end{array}$ \\
\hline Diet and nutrition & $\begin{array}{l}\text { The link between diet and health and well being. Includes health benefits of } \\
\text { fruit \& vegetable, availability and consumption of junk food, product } \\
\text { formulation e.g. additives, salts, fat etc. Plus R and D in relation to Diet } \\
\text { and Nutrition. }\end{array}$ \\
\hline Education in schools & $\begin{array}{l}\text { Provision of cooking and information about food nutrition and food } \\
\text { production through school classes, plus practical experience and } \\
\text { involvement of children in growing and preparing food. }\end{array}$ \\
\hline Food and drink advertising & $\begin{array}{l}\text { Regulation around advertising and promotion of food and drink high in fat, } \\
\text { sugar and salt especially that aimed at children audiences. }\end{array}$ \\
\hline Food labeling & $\begin{array}{l}\text { Provision of information about nutritional content of food, its origin } \\
\text { (including environmental issues) and ingredients on its packaging, } \\
\text { including information provision for food provided by the catering sector. }\end{array}$ \\
\hline Food safety & $\begin{array}{l}\text { Health and safety standards in production, storage and transportation of } \\
\text { food and drink. Raising awareness about health and safety when cooking } \\
\text { and storing food at home. }\end{array}$ \\
\hline Grow your own & $\begin{array}{l}\text { Environmental impact of households growing own food as well as its effect } \\
\text { on overcoming the problem of food deserts, and improved understanding } \\
\text { of where your food comes from. }\end{array}$ \\
\hline
\end{tabular}


Table A-1. Cont.

\begin{tabular}{|c|l|}
\hline Health promotion & $\begin{array}{l}\text { Promotion of healthy eating and diet through media. Also promotion of } \\
\text { healthy eating and diet by the public sector through media and wider } \\
\text { initiatives. Plus ethical behavior of businesses in facilitating healthy diets. }\end{array}$ \\
\hline Local food \& local communities & $\begin{array}{l}\text { The role of local food producers and processors in supplying the } \\
\text { surrounding communities with fresh food, outdoor activities such as "pick } \\
\text { your own" farms. }\end{array}$ \\
\hline Local food \& local economies & $\begin{array}{l}\text { The impact of Scottish food industry on regional employment, income and } \\
\text { general welfare. Including Government financial support for farmers and } \\
\text { the food sector. }\end{array}$ \\
\hline Prices-consumer & $\begin{array}{l}\text { Prices paid for food by the consumer, mainly refer to prices set by the } \\
\text { retail and catering sectors. }\end{array}$ \\
\hline School \& hospital meals & $\begin{array}{l}\text { The content of meals provided in public establishments (e.g., hospitals, } \\
\text { schools etc.) with regards to their quality, nutritional content and } \\
\text { freshness. }\end{array}$ \\
\hline Traceability & $\begin{array}{l}\text { Availability of information at each stage of the supply chain about the } \\
\text { origin of food and the route it has travelled. }\end{array}$ \\
\hline
\end{tabular}

(C) 2011 by the authors; licensee MDPI, Basel, Switzerland. This article is an open access article distributed under the terms and conditions of the Creative Commons Attribution license (http://creativecommons.org/licenses/by/3.0/). 